\title{
Tula sin censura: un recorrido por la «otra versión» del clásico de Miguel Picazo
}

\section{Tula without censorship: a survey of the «other version» of Miguel Picazo's classic}

\author{
Gemma SuÑÉ Minguella \\ American University, Washington D.C. \\ suneming@american.edu \\ ORCID ID: 0000-0002-8350-2975
}

\begin{abstract}
Resumen: Desde su éxito en el Festival Internacional de cine de San Sebastián (1964), La tía Tula de Miguel Picazo se convirtió en uno de los hitos del "Nuevo cine español” y, con el tiempo, en uno de nuestros clásicos. Sin embargo, tal y como profetizó el propio García Escudero, Director General de Cinematografía durante esos años de "aperturismo" del régimen franquista, el perjuicio de haber sido censurada en exceso no ha dejado de acompañarla casi como un atributo ya inherente a ella. Además, el hecho de que se destruyeran los negativos censurados no habría hecho sino contribuir a esta leyenda. Nos proponemos en este artículo comparar la película que ha llegado hasta nosotros con el guion publicado en 2005 en ocasión del 40 aniversario de su estreno. Para ello tendremos en cuenta, no solo las escenas y planos cortados por la censura, sino también todas aquellas modificaciones realizadas por el propio Picazo en su tarea de poner en escena su obra. Nuestro recorrido nos desvelará una versión más compleja y matizada de los principales personajes, así como un retrato mucho más minucioso, incisivo y hasta mordaz de la sociedad provinciana de principios de los años sesenta.
\end{abstract}

Palabras clave: adaptación fílmica, guion fílmico, Tula, Unamuno, Picazo, censura, García Escudero, Nuevo cine español.

\begin{abstract}
Since its success at the San Sebastián International Film Festival (1964), Miguel Picazo's La tía Tula has become one of the milestones of the "New Spanish Cinema" and, over time, one of our classics. However, as García Escudero himself predicted, General Director of Cinematography during those years of "openness" of the Franco regime, the prejudice of having been censored in excess has not ceased to accompany the film, almost as an attribute already inherent to it. Moreover, the fact that the censored negatives were destroyed would have only contributed to this legend. In this study, we intend to compare the film that has reached us with the script published in 2005 on the occasion of the 40th anniversary of its premiere. In doing so, we will take into account not only the scenes and shots cut by the censorship, but also all the modifications made by Picazo himself in his task of staging his work. Our journey will reveal a more complex and nuanced version of the main characters, as well as a much more detailed, incisive and even scathing portrait of the provincial society of the early sixties.
\end{abstract}

Key Words: film adaptation, screenplay, Tula, Unamuno, Picazo, censorship, García Escudero, New Spanish cinema. 


\section{Gemma Suñé Minguella}

\section{INTRODUCCIÓN}

Miguel Picazo, creador de la cinematográfica tía Tula, se lamentaba de que su película, con más de ocho cortes practicados por la censura, había sido prácticamente reducida a un tráiler de sí misma ${ }^{1}$. Dichas declaraciones le valieron el distanciamiento de García Escudero, que, desde su nombramiento como Director General de Cinematografía, había considerado a los titulados de la Escuela Oficial de Cine, como Picazo, la mejor baza de su política de apertura. Además, García Escudero había renovado la composición de la Junta y el Código de Censura con criterios más cinematográficos ${ }^{2}$, pero comprensiblemente, la mera existencia de un tamiz censor provocaba no poca indignación en los realizadores que habían de soportar la mutilación de sus obras. En esos años, además, la burla a la censura de Viridiana ${ }^{3}$ había provocado mucho revuelo, lo cual había de perjudicar a la película de Picazo, pues los censores se hallaban especialmente susceptibles a toda alusión mordaz al tema religioso.

El guion de La tía Tula, firmado en un principio solo por Picazo y López Yubero, fue presentado a la Junta censora en mayo de $1962^{4}$, y fue autorizado - con reticencias- por cuatro de los seis censores que lo analizaron. El denominador común de sus informes era su temor a que se hiciera un tratamiento ridículo e histérico de la religiosidad de Tula, así como su poca confianza en la calidad del guion. No obstante su autorización, y quizá para aprovechar las recientes remodelaciones de la Junta y las Normas de censura, los guionistas decidieron presentar una segunda redacción un año más tarde, añadiendo entonces a Hernán y

\footnotetext{
${ }^{1}$ «Una vez recibido en la productora el informe de la comisión de censores [...], hice las entrevistas de prensa declarando que la película les había estropeado la digestión a los censores y que habían dejado un tráiler» (Hernández, 2003: 327 $328)$.

${ }^{2}$ Reorganización de la Junta de Clasificación y Censura (Decreto 2373 de 20 de septiembre de 1962), nuevas Normas de Censura Cinematográfica (Orden de 9 de febrero de 1963), completadas con las nuevas Normas para la Censura de Guiones (Orden de 16 de febrero de 1963). A pesar de la censura, durante los algo más de cinco años que García Escudero estuvo al frente de la institución (junio 1951febrero 1952 y 1962-1967) el «Nuevo cine español» vio la luz y marcó el camino. Sus innovaciones legislativas perdurarían, con algunas variaciones, hasta la llamada Ley Miró de 1983 (Martínez, 2006: 333-352).

${ }^{3}$ El régimen franquista, haciendo gala de aperturismo, autorizó a Buñuel el rodaje en España, pero este se burló de la censura llevándose la película a París y posteriormente estrenándola en Cannes con gran éxito (Palma de Oro). L'Osservatore Romano, periódico oficial del Vaticano, calificó la película de blasfema y pidió la excomunión de todo el equipo. Las autoridades franquistas, por su parte, tras cesar a Muñoz Fontán, a la sazón Director General de Cinematografía, negaron la autoría española del film, que solo se pudo estrenar cuando más tarde lograron adjudicarle la nacionalidad mexicana.

${ }^{4} 11$ de mayo de 1962. Expedientes de La tía Tula, núms. 67-63 y núms. 107-63. Secretaría de Estado para la Cultura. MEC (Vaquerizo García, 2014: 155).
} 
Sánchez Enciso. Aunque esta vez ninguno de los ponentes la desautoriza, continúan advirtiendo que el tratamiento del personaje de Tula y sus amigas puede acabar creando «un clima de ñoñería y ridiculez religiosa, o de vaciedad o fariseísmo», y que Tula es susceptible de ser presentada «no como una mujer virtuosa, sino como una mujer reprimida», lo cual, añaden, contravendría la Norma 14 de Censura ${ }^{5}$.

Una vez rodado el film, en febrero de 1964, la Junta de Clasificación y Censura condicionó la exhibición de la película a la supresión de algunos planos, escenas y hasta palabras que, según precisaban, no se hallaban en el guion ${ }^{6}$. Los productores presentaron un recurso administrativo, pero la Junta se reafirmó en su primer dictamen, aunque admitió la necesidad de conservar parte de la escena de Ramiro con Juanita para la coherencia de la trama. La indignación de Picazo, pues, no carecía de fundamento. En su diario de esos años, García Escudero recordaba el éxito en San Sebastián de la película y consideraba que -dada la ovación recibida en el Festivallos reproches de Picazo eran algo exagerados. Aun así, profetizaba que los cortes a La tía Tula difícilmente quedarían en el olvido y reaparecerían con el tiempo. No se equivocaba (García Escudero, 1978: 130).

En el año 2004, cuando se cumplían cuarenta años del exitoso estreno de La tía Tula, la Diputación Provincial de Jaén conmemoraba el aniversario con un homenaje a su creador. Un año más tarde, la misma Diputación decidía publicar el guion de la película, recuperando así la integridad del proyecto escrito, pero no la obra como tal, irrecuperable por la destrucción del negativo. Según Actas de la censura, se cortaron 4 minutos y 47 segundos, aunque Picazo aseguraba que se habían llegado a cortar «escenas completas de seis minutos» (Iznaola, 2004: 34). El guion no pretendía "adaptar" literalmente el texto literario de Unamuno, sino más bien versionarlo a través del tamiz de la realidad y la cotidianeidad de sus creadores: M. López Yubero y el propio Picazo, que era quien marcaba las directrices, con la colaboración de J. M. Hernán y Luis Enciso. Según explica Hernán, cada uno de ellos aportó al guion «su experiencia original y cultural» y las decisiones las tomaban más por convencimiento que por consenso: «los personajes debían decirlo así, y no de otra manera $[\ldots]$.

\footnotetext{
${ }^{5}$ Orden de 9 de febrero de 1963. Informe de la Comisión Delegada para censura de guiones cinematográficos. Sesión celebrada el 6 de mayo de 1963. Expedientes de La tía Tula, núms. 67-63 y 107-63. Secretaría de Estado para la Cultura. MEC (Vaquerizo García, 2014: 158).

${ }^{6}$ Las supresiones propuestas son: Rollo 3: Suprimir plano de Ramiro y Ramirín a la puerta del cementerio, con el aviso al fondo, en que se prohíbe la entrada sin medias, etc. Rollo 7: Supresión íntegra de la lectura espiritual en el Centro Femenino. Suprimir la palabra «Beata» que Ramiro lanza a su cuñada después del acoso. Rollo 8: Suprimir la alusión a los cascos de guerra. Rollo 9: Suprimir la frase alusiva a las iglesias del pueblo. Rollo 10: Cortar la escena de cama cuando Ramiro da el primer beso a Juanita. Expedientes de La tía Tula, núm. 29.867 y núm. 32.801. Secretaría de Estado para la Cultura. MEC (Vaquerizo García, 2014: 161).
} 


\section{Gemma Suñé Minguella}

Hay muchas frases que no nos abandonarán [...] y que nacieron de la fiebre creativa que nos impulsaba, basada en métodos de expresión realistas y cotidianos» (Picazo et. al., 2005: 44).

Nos proponemos en este artículo comparar el guion original con la película final, teniendo en cuenta y valorando no solo las escenas y planos cortados por la censura, sino también todas aquellas alteraciones y supresiones realizadas por el mismo Picazo en su tarea de ponerla en escena. Nuestro recorrido nos permitirá apreciar con detenimiento el proceso creativo del cineasta, así como valorar cómo afectaron los cambios y supresiones a la película que ha llegado hasta nosotros, la cual es tan solo una versión de la obra que pudo haber sido. Si no un "tráiler" de sí misma, como decía Picazo, sí bastante distinta. Como veremos, en el guion sigue latente otra versión de Tula y hasta otra versión de Ramiro, así como una visión mucho más prolija, penetrante y hasta mordaz de la sociedad provinciana de principios de los sesenta.

\section{Del GUion a la Película}

La escena que abre la película nos sitúa directamente en el día del entierro de Rosa, la hermana de Tula y esposa de Ramiro. Aunque el guion no alude a ello, se oyen unas campanas, pero no precisamente de toque de difuntos, sino simplemente de llamada a oración, quizá para evitar el excesivo tono fúnebre de la escena. Un largo travelling nos deja ver la corona de difuntos colgada de un trípode y unas piernas de niño por debajo que la transportan. Es una imagen muy sugerente y hasta un punto cómica, pues casi parece una «corona andante». El guion preveía una mañana de enero soleada y el niño caminando por un paseo sin asfaltar, «esforzándose en alzar la corona para que las hojas negras y las flores malvas no arrastraran por el barro», ya que la lluvia de la madrugada habría creado algunos charcos. En el film, sin embargo, no hay ningún indicio de que haya llovido. Desconocemos a qué fue debido este cambio, aunque sin duda contribuye a la tan alabada sobriedad de su puesta en escena, pues elimina otros detalles que la cámara hubiera captado, como el agua de los charcos reflejando «la arquitectura del paseo», el aire de la mañana y los zapatos del chico hundiéndose en el barro. Parte de la inscripción de las cintas de la corona, «La Rama Femenina de...» (se supone que la parte ilegible sería «de la Acción Católica»), no se verá hasta que Herminia y Amalita aparezcan en escena recibiendo la corona que ellas mismas habrían encargado, y no al principio como preveía el guion. Herminia, por cierto, se suponía que debía ser morena, pero la elección de Emilia Gutiérrez Caba para el personaje haría tal detalle totalmente prescindible.

Tras la toma en que Tula le agradece a Herminia la compra de la corona y su ayuda encargándose de su sobrina, el guion nos llevaba a la cocina donde la cocinera había teñido de negro los zapatos de Ramirín, y donde Tula había de cortar las borlas coloradas de sus zapatillas. El guion 
preveía que, inmediatamente tras el plano de las tijeras cortando las borlas, debía derramarse el líquido del cazo donde se preparaba la tila para el niño. Una escena de una diáfana simbología que adelantaba el drama que iba a desplegarse ante nuestros ojos: una «castración» y un desborde incontrolable de la libido. Interesante manera de poner en guardia al espectador, sin duda, pero acaso excesivamente gráfica. Las zapatillas de Tula serán mencionadas varias veces a lo largo del guion, así como el andar suave y silencioso de Tula por la casa, que también es perceptible en la película. Sin embargo, serán sobre todo las manos de Tula las que acapararán la atención. Manos que atienden sin descanso a las labores de la casa, y que serán también objeto de deseo por parte de un Ramiro enfermo en la conocida escena en que Tula lo acicala como a un niño.

En la secuencia inicial se depuró también la imagen de los ancianos del asilo y los tres curas con monaguillo que, con la cruz alzada, debían liderar la procesión fúnebre; en su lugar solo vemos a dos monjas sentadas, extrañamente inmóviles y con los ojos cerrados, que no se inmutan ni cuando se llevan el ataúd. Es presumible que el propio Picazo, sabedor de las suspicacias que creaba, decidiera reducir la presencia del clero, aunque la imagen de las dos monjas resulta, cuando menos, inquietante, además de algo buñueliana-surrealista. Abundando en la sobriedad de la puesta en escena, y en las previsibles objeciones de los censores, la película tampoco captará los rezos, ni el cantar monótono de los misereres desde la calle, ni los tópicos lamentos de las mujeres «llevándose el pañuelo a los ojos», tal y como sugería el guion, sino tan solo el sonido tenue de las campanas de fondo, que se extingue cuando se llevan el ataúd para que podamos discernir mejor el sonido de la madera tropezando contra las paredes al bajar, y el silencio. Un silencio que sostendrá la figura de Tula hasta sentarse en una silla, cuando la más que pertinente música de Antonio Pérez Olea la exalta e individualiza a los ojos del espectador, mientras el título y los créditos se superponen a su imagen en un plano medio que dura exactamente 2 minutos y 32 segundos. No creo exagerar si sostengo que este largo plano de Aurora Bautista es tan paradigmático del cine español como puede ser el ojo rasgado de Un perro andaluz o el «riégueme» de Carmen Maura en La ley del deseo. Una imagen icónica, esencial, de nuestra cultura.

Comenta Javier Ocaña que la mirada de Tula en esta toma «dirigida hacia ninguna parte, aparentemente pensativa y en realidad desconcertada, es la mirada de una España anulada, de un país que no sabe hacia dónde encaminar el paso» (Ocaña, 2004: 193). Algo parecido, restringido al ámbito de la mujer española, apuntaría Edith Laurie en su reseña de 1965 para Film Comment, cuando sostiene que la película retrata el «just discovered sense of what it is to be a Woman in Spain -young woman, matron, spinster» (Laurie, 1965: 40). Sin duda. Su calidad de clásica hace que esta película sea una fuente inagotable de sugerencias, ya sean sociológicas, históricas o psicológicas, y todas ellas convergen en esta 


\section{Gemma Suñé Minguella}

imagen de Tula tan rica y sobria a la vez, y tan audaz en su duración, puesto que la imagen no es un fotograma; es el personaje el que se ensimisma, pero no la cámara, que sigue filmándola, tal y como nos confirma el movimiento de otros personajes a través de la rendija de la puerta. Pero además de las opiniones antes reseñadas, intuimos que dicha imagen alude también a la iconografía religiosa. El ceño levemente fruncido, la mirada ligeramente hacia abajo, la boca entreabierta, la expresión de absoluta pesadumbre, elementos todos que nos remiten a la iconografía mariana, y hasta quizá a alguna imagen de la infancia cristalizada en la mente de Picazo, como las esculturas de la Virgen realizadas en torno a esos años por Sebastián Santos Rojas, frecuentes en las procesiones de Semana Santa ${ }^{7}$. Es la imagen de la maternidad/sororidad en duelo y sumida en el pesar, y es también en esta expresión de Tula donde converge toda la prehistoria del personaje que el film omite. Dos minutos y treinta y dos segundos en los que el espectador imagina o recuerda - si conoce la novela- lo que no se le cuenta, pero que ha sido magistralmente evocado por la escena inicial.

Resulta curioso que también Unamuno, en un primer momento, concibiera el inicio de su nivola en el momento en que fallece la hermana de Tula, es decir, en lo que posteriormente se convirtió en el capítulo VII de la novela, y que Picazo recupera como una suerte de introito. En Unamuno, sin embargo, habría sido impensable la recreación social y cultural de un entierro, fiel como era a la idea de que «la realidad es la íntima», y no «las bambalinas, ni las decoraciones, ni el traje, ni el paisaje, ni el mobiliario, ni las acotaciones, ni...» (Unamuno, 1920: 17). De hecho, fallecen cuatro personajes en la novela (el tío Primitivo, Rosa, Ramiro y Manuela), y el único detalle que nos da el novelista curiosamente solo respecto a los hombres- es que la tarea de amortajarlos corre a cargo de Tula ${ }^{8}$.

La siguiente secuencia, todavía con la mención en la pantalla de haber sido declarada «De Especial Interés Cinematográfico»" se abre con un

\footnotetext{
${ }^{7}$ Hay una en concreto de una semejanza asombrosa: Nuestra Señora de las Penas, de la Hermandad de Santa Marta, que se conserva en la Parroquia de San Andrés, en el barrio sevillano de La Encarnación. Fue realizada por Sebastián Santos Rojas en 1958. Resulta curioso, además, que pertenezca a la hermandad de Santa Marta, patrona de las cocineras y amas de casa. Marta (santa Marta de Betania) sobresale como figura de «hermana» (de María y Lázaro) en el Nuevo Testamento.

${ }^{8}$ Véanse los capítulos V y XVI de la novela.

${ }^{9}$ García Escudero sustituyó la categoría de «Interés Nacional» por «Interés Especial» para tres tipos de proyectos y una clase de películas: a) Los que ofreciendo suficientes garantías de calidad, contuvieran realmente valores morales, sociales y políticos; b) Los indicados para menores de 14 años; c) Con suficiente ambición artística, especialmente cuando facilitaran la incorporación a la vida profesional de los titulados de la Escuela Oficial de Cinematografía; d) Las películas que obtuvieran un gran premio en los festivales internacionales de categoría A. Su adjudicación suponía, además de la subvención automática equivalente al 15\% de su recaudación
} 
zoom desde un plano detalle de la mano derecha de Tula recogiendo el mantel hasta un plano medio en que reconocemos a Ramiro y los niños sentados a la mesa. Con la frase de Tula: «Esta tarde es el último Rosario» se solventa la elipsis temporal que va de una secuencia a otra. No sabemos cuánto tiempo ha pasado, pero el suficiente para que un poco más tarde, ante el desconsuelo de la niña, Tula ejerza ahora sí de Virgen con niña en los brazos y sentencie que «mañana mismo vas a volver al colegio», decisión que incluirá al niño, que ha permanecido en pie junto a ellas, a todas luces muy necesitado también de consuelo maternal. Cuando le sugiere a Ramiro que se eche un rato, él le contestará con determinación: «Yo también voy mañana a la oficina».

Las diferencias más relevantes de esta escena con lo sugerido en el guion son los cantos diegéticos de los niños en la calle, y algunos detalles de Ramiro curioseando los objetos que adornan la casa de Tula. La tía Tula fue una de las primeras películas en usar el sonido directo, lo cual contribuye al hiperrealismo de su narrativa. En el guion se aludía simplemente a voces infantiles que cantaban:

Ha dado la una.

Cierran los conventos.

Y las pobres monjas,

se quedan adentro.

Y os monecillos

van a la cocina

Y hacen chocolate

para las vecinas.

Las vecinas dicen:

Uy, que rico está.

Hazme otro poquito,

para merendar.

Al ponerlo en escena, sin embargo, se cambiará la canción (evitando de nuevo aludir al clero), y atisbaremos a través de los ojos de Ramiro cómo un grupo de niños pretende irrumpir en el corro de unas niñas que cantan y tocan las palmas al son de la canción tradicional toledana ;Ay! Chúngala, en la que se evidencia la hipocresía de las mujeres de clase acomodada (usuarias del decimonónico polisón):

¡Ay! Chúngala, calaca, chúngala,

¡Ay! Chúngala, calacachún

¡Ay! Chúngala las señoritas

que llevan el polisón.

Las señoritas de ahora

dicen que no beben vino

en taquilla (aplicable a todas las películas), doble cuota de pantalla, anticipo de un millón de pesetas y permisos de importación a las distribuidoras que las incluyeran en sus listas (Martínez, 2006: 339-340). 


\section{Gemma Suñé Minguella}

y debajo el polisón

llevan el jarro escondido

(Cabañas Alamán, 2001: 54).

El hecho de que Ramiro contemple la escena es de lo más significativo, pues el guion insistía en que había que vérsele tedioso e inquieto a la vez, aspirando «casi con rabia el humo del pitillo». Al contemplar la escena de cierta tensión entre niñas y niños en la calle, sin embargo, expresará curiosidad, casi como aliviado ante la certidumbre de que la vida sigue tras los muros de la casa. Justo después, por cierto, eructará. La palmaria «fisicidad» del personaje se hace obvia incluso en estos pequeños detalles.

La ambientación de la casa de Tula tiene especial relevancia tanto en el guion como en la película, pues había que recalcar «los muebles antiguos, oscuros y un poco barrocos del tío canónico», así como «los cuadros de familiares» que felizmente no se exageran en la puesta en escena, aparte del de «la prima Gabrielita» que sí tendrá relevancia. Entre esos objetos vemos en pantalla un busto (que había de ser de Beethoven), y la foto de Pío XII (que tenía que haber estado enmarcada en terciopelo morado), un gato de mayólica, y una virgen de Lourdes con música. El guion señalaba que Ramiro, aburrido, cogía la pequeña imagen de la Virgen, la cual se ponía a sonar el Ave María, y aturdido la volvía a colocar en su sitio. Este gesto se omite en la película, quizá en aras de la reducción de alusiones religiosas susceptibles de poner en guardia a los censores, o simplemente por economía y sobriedad. La foto de Pío XII, sin embargo, sigue ahí, y es obvio que la cámara nos invita a reconocerla. Suponemos que la imagen sería también del tío canónico, aunque no parece que a Tula le sobre, a pesar de que, si nos atenemos a la contemporaneidad de la película, debería ser Juan XXIII el que figurara en el retrato, el impulsor del tan necesario aggiornamento de la Iglesia Católica a través del Concilio Vaticano II. El hecho de que sea Pío XII pues, y no su sucesor, es una clara declaración de principios, pues fue Pío XII el que, tras varios desencuentros, accedió a suscribir el Concordato entre la Santa Sede y España en 1953. Ello supuso para el régimen franquista el reconocimiento internacional de algún estado (unos meses más tarde le seguirían los «Pactos de Madrid» con EE.UU.), y para la iglesia un afianzado poder y privilegios. La elección de Picazo, en consecuencia, alinea a Tula con el catolicismo más conservador y afín al régimen.

La película destaca por la meticulosidad con la que se testimonian numerosos usos, costumbres y objetos caseros de la época, lo cual, sumado al protagonismo femenino, situaría a La Tía Tula en la tradición de las grandes novelas realistas del siglo XIX. El guion incluía incluso más detalles y escenas que contribuían a esta carga costumbrista de la obra, como breves diálogos y descripciones (de lugares y personajes) que captaban la cotidianeidad pública y doméstica de aquella sociedad. 
La secuencia que incluye la conocida anécdota de Ramiro en camiseta y el consiguiente reproche de Tula, se iniciaba mostrando a Tula y a otras mujeres saliendo de misa de ocho. La toma, conservada en fotograma, se desarrollaba a la puerta de la bellísima Concatedral de Santa María de Guadalajara $^{10}$. El guion describía cómo algunas de las mujeres se sacaban el velo y lo guardaban cuidadosamente junto al misal, se aludía a la Calle Mayor silenciosa, a los barrenderos, a las limpiadoras fregando la puerta del Casino, y hasta a una pareja de la Guardia Civil llevando a la cárcel, desde la estación, a una cuerda de presos. Tula se detenía a comprar unos churros en un puesto de la plazuela, y luego seguía con prisa hacia su casa. La película da inicio a la segunda secuencia precisamente aquí, cuando Tula entra en su casa y -tras intercambiar unas palabras con Tulita desde la entrada - va a la cocina y deposita los churros en un plato. Resulta difícil comprender cómo pudo eliminarse tan sugerente escena ${ }^{11}$, a no ser que la imagen de la cuerda de presos hubiera desatado suspicacias. De hecho, desde la fundación de la Guardia Civil, esta fue una de las tareas más ingratas para el cuerpo y peor vistas por la población, de ahí que quizá molestara verla en escena. Sin embargo, además de reflejar una escena real, y aparte de recordarnos la memorable escena de los galeotes en el Quijote, no podemos evitar pensar que quizá fuera también una suerte de guiño a la película de Pedro Lazaga Cuerda de presos, de 1955, con lo cual nos encontraríamos con un magnífico ejemplo de «cine dentro del cine» ${ }^{12}$.

Otro ejemplo de costumbrismo, en este caso con ciertos tintes esperpénticos, era la presentación que se hacía en el guion de la madre del pretendiente, Emilio (Chiro Bermejo). La entrañable actriz de origen ecuatoriano Julia Delgado Caro era Doña Cinta, la dueña de la confitería donde Ramiro acude para hablar con Emilio. Su aparición, que debía hacerse cuando la campanilla de la puerta la despertaba sobresaltada, aportaba cierto tono esperpéntico a la escena, ya que se comparaba su figura con el papel de las paredes con «flores y pájaros absurdos», Doña Cinta -leemos- «es como un pájaro más. Arrugado» (Picazo et al., 2005: 106). En su interacción con Ramiro veíamos cómo lo acomodaba en una mesa camilla con brasero y, tras un repentino gemido para recordar a la difunta Rosa, se disculpaba por no haber podido ir al entierro debido a cuestiones de salud. La película, sin embargo, inicia la escena con Emilio y Ramiro ya sentados a la mesa y Doña Cinta sirviéndoles vino moscatel, a

\footnotetext{
${ }^{10}$ La exposición 50 Años de la Tía Tula, organizada por la Academia de las Artes y las Ciencias Cinematográficas de España del 3 de octubre al 7 de noviembre de 2014, incluyó buen número de fotogramas correspondientes a escenas finalmente eliminadas de la película.

11 Sugerente y seguramente de enorme valor ambiental y emotivo, como el inolvidable «despertar» de la ciudad en Calle Mayor (1956) de J. Antonio Bardem.

${ }^{12}$ Pedro Lázaga (1918-1979) director y guionista español que, por cierto, debutó como guionista de otra adaptación de una nivola unamuniana: Abel Sánchez (1946) de Carlos Serrano de Osma.
} 


\section{Gemma Suñé Minguella}

pesar de la hora del día porque «el Moscatel es un tónico», según doña Cinta. Antes de que Emilio muestre y lea a Ramiro la carta de Tula, aparecía una clienta «viejecita» que desde la puerta reconvenía a Emilio por la dureza de las ensaimadas, lo cual provocaba una mirada de complicidad entre madre e hijo. La película, sin embargo, también prescindió de esta anécdota. Es posible que en la puesta en escena se considerara que el personaje de doña Cinta ya quedaba plenamente perfilado con su sola presencia sirviendo el vino, y sobre todo cuando al final interrumpe a su hijo diciendo: «Deja, hijo... Eso Ramiro lo da por descontado. Todo el mundo sabe que somos muy formales» (Picazo et al., 2005: 110). La economía y la trabazón de la trama salen reforzadas, sin duda, pero creemos que las referencias al reciente funeral de Rosa habrían ayudado al espectador a juzgar con mayor comprensión la actitud de Tula.

Otra escena que habría contribuido a ello, y que al tiempo habría redundado en una caracterización más compleja de Ramiro, tenía lugar después de la comunión y antes de que veamos a Ramiro sentado en el Merendero observando a las chicas modernas - «cachondas» se las llama en el guion-(Picazo et al., 2005: 156). Ante el peso abrumador de «dos días de fiesta» que a Ramiro se le hacen interminables, y puesto que su cuñada le ha animado a salir, a ir al Casino o a tomar el aire, Ramiro se dirigía a la casa donde había vivido con Rosa y se detenía un momento frente a la ventana de la cocina. Poco después, la nueva inquilina asomaba la cabeza y - tras llamar a una vecina- observaba a Ramiro con curiosidad. De nuevo, quizá se pensó que el deambular de Ramiro entre el Merendero y la colina donde acuden las prostitutas de Madrid era suficiente para dibujar la abulia, el deseo reprimido y el aislamiento social del personaje. Sin embargo, la referencia al recuerdo de su difunta esposa le habría conferido mayor profundidad psicológica, recordándole al espectador que su apatía era fruto del duelo.

La escena de los colchoneros, manifiestamente simbólica y de gran carga costumbrista, también acabará modificada respecto a su proyecto inicial. Recordemos que esta secuencia va justo después del incidente en que un Ramiro enfermo había acariciado con su mejilla la mano de Tula, provocando la indignación de ella ${ }^{13}$. El guion intercalaba entre ambas escenas la visita de Ramiro y su hijo al cementerio, con un plano censurado de un cartel real (del cementerio de Guadalajara) prohibiendo el paso a las señoras sin medias y a las parejas poco recatadas ${ }^{14}$ (Iznaola, 2004: 35). En

\footnotetext{
${ }^{13}$ Un detalle nada desdeñable de la escena en la habitación, es que el guion hacía que Tula mirara el retrato de Rosa antes de salir. En la película final hay una notoria intención de borrar el recuerdo de Rosa, lo cual redunda negativamente en la percepción del personaje de Tula, y hasta cierto punto, también del personaje de Ramiro.

${ }^{14}$ El cartel real que Picazo puso de relieve con su cámara, pues situó a sus personajes flanqueándolo, se hallaba a la entrada del cementerio de Guadalajara y decía así: «Cementerio lugar sagrado. Se prohíbe el paso en el cementerio a las
} 
la película, sin embargo, la escena del cementerio seguirá a la de Ramiro y Tula discutiendo a raíz de la carta de esta a Emilio, y justo antes de la secuencia de los renteros y Ramiro enfermo en la habitación. El cambio de orden de las escenas favorece sin duda la solidez y continuidad de la trama, puesto que a los escrúpulos de Tula ante la caricia de Ramiro se enlazará esta secuencia de los colchoneros, que es casi una alegoría de la «penitencia por pecado de lujuria». El guion otorgaba amplio protagonismo a Tulita, que no había ido al colegio porque estaba enferma de anginas como su padre. En cuanto llegaban los colchoneros, la niña los seguía juguetona hasta la terraza, saltando a la pata coja o acurrucándose en el suelo y sacando la nariz por la barandilla de la terraza, mientras murmuraba el «Yo pecador». Como la ventana de la cocina daba a la terraza, Tula se asomaba de vez en cuando formando parte del encuadre. El guion enfatizaba el aspecto humilde de los colchoneros. Ella, que al agacharse «enseñaba el comienzo de los pechos delgados y flácidos» replicaba a Tulita que siempre había sido «un espantajo», mirando al marido que cubierto con una «boina sebosa» vareaba sin descanso la lana y ni se molestaba en asentir (Picazo et al., 2005: 127). El aspecto escuálido de la colchonera le recordaba a Tulita la prima tísica Gabrielita que «murió en olor de santidad» ${ }^{15}$, pero como los colchoneros no le hacían caso, la niña acababa requiriendo que Tula, desde la cocina, confirmara la veracidad de la historia. A continuación, caían unas gotas de lluvia y Tulita, pasando las manos por la baranda herrumbrosa salmodiaba: «Ya está lloviendo. Santa Dei Genitrix. Ya está lloviendo...». Después se dirigía al comedor para descolgar el retrato de Gabrielita y se metía con él en el cuarto de los trastos viejos. La película inicia la secuencia justamente aquí, cuando Tulita abre el baúl y se atavía con la capulina de canónico y el sombrero femenino.

A juzgar por los fotogramas conservados ${ }^{16}$ esta parte omitida en la versión final de la película sí fue rodada, al igual que la escena ya comentada de la salida de la iglesia a las ocho de la mañana. Su supresión, además de arrebatarnos unos minutos de la excelente actuación de la niña Mari Loli Cobos, resta coherencia a la escena, puesto que no acaba de

señoras y señoritas que vayan sin medias y a las parejas que no guarden la debida compostura y moralidad». En una entrevista para el programa Versión Española de RTVE (25/04/2003), Picazo ironizaba con el hecho de que los censores cortaban incluso la propia realidad, y se preguntaba por qué lo aceptaban en un ámbito real pero no podían aceptar de ninguna manera que figurara en una película.

15 «En olor de santidad» se refiere a uno de los atributos que rodean el fenómeno de la santidad cristiana, como la incorruptibilidad del cadáver o, en este caso, el aroma que de él se desprende. La santidad era interpretada como una virtus, esto es, una energía que se manifestaba a través de un cuerpo: «Avant d'etre une qualité de l'ame ou un état spirituel, la sainteté, dans la mentalité commune, est d'abord une énergie (virtus) qui se manifeste à travers un corps. Sa présence était perçue d'après un certain nombre d'indices d'ordre physiologique» (Vauchez, 1988: 499).

${ }^{16}$ Véase nota 10 sobre la exposición 50 Años de la Tía Tula. 


\section{Gemma Suñé Minguella}

entenderse por qué Tulita decide súbitamente llevar en procesión el retrato de su prima Gabrielita por la terraza, casi estorbando la tarea de los colchoneros. La mujer, por cierto, ya no lleva escote, sino que se la ve en un segundo plano y totalmente cubierta. Mientras que su marido no lleva ninguna «boina sebosa» ni va arremangado, sino en manga corta. La leve «denuncia social» quedó al final en casi nada. La fuerte crítica a la moral represora de la época, sin embargo, sigue patente a lo largo de toda la secuencia gracias al sonido diegético de la vara flexible, con punta curvada, con la que el colchonero varea los montones de lana. Intencionadamente, el sonido de este «flagelo» abarca toda la secuencia, sirviendo de música de fondo al descubrimiento de las fotos eróticas de Ramirín, la procesión de Tulita con caída y rotura de los cristales incluida, hasta la imagen de Ramirín, con la teja del tío canónico en la cabeza, leyendo las cartas cuasi eróticas de su padre a su madre. La simbología es meridiana, aunque finalmente también se eliminara un fragmento del canto que entona Tulita con el retrato de su prima. Dice así: «Si me preguntan a mí / como se llama mi amado, / Yo les responderé así: / Es Jesús Sacramentado» (Picazo et al., 2005: 130). No nos cabe ninguna duda de que toda esta secuencia, sin cortes, habría creado una excelente simetría con la posterior escena censurada en el Círculo de Acción Católica, donde se reflexionaba sobre la virginidad. Solo que si bien allí eran las mujeres adultas las que eran aleccionadas, en la escena de los colchoneros vemos cómo calaba la educación religiosa y la moral social en la mente de los niños, especialmente en Tulita, la niña.

Volviendo a la escena del cementerio censurada en parte, es interesante recordar que Picazo, en aquel momento, se lamentaba menos por la pérdida del plano del cartel que por la pérdida del sentido de la escena. Según explicaba, la secuencia en su totalidad había de comunicar la sensación de soledad de Ramiro y su hijo, así como el hecho de que la figura de Tula estaba eclipsando en sus mentes a la figura de la madre y esposa, ahora ya definitivamente muerta (Monleón, 1964: 45-46). De ello da cuenta el gesto de Ramiro escribiendo el nombre de Tula con una pluma que encuentra por el suelo, pero no tanto el resto de la secuencia, que aparece sobre todo marcada por la desesperación de la esposa de un suicida. Lamentable corte, en efecto, pues no hay duda de que el personaje de Ramiro se resiente de un escaso desarrollo en pantalla tanto de su duelo psicológico, como de su progresivo apego por Tula más allá de lo erótico.

La secuencia de la primera comunión aparece también modificada en la película respecto al guion. Según Picazo «suprimieron [los censores] gran parte de la secuencia de la primera comunión» (Castro, 1974: 332). De nuevo, se proyectaba aquí una amena escena costumbrista con un grupo de familiares, monjas y niños con sus vestidos de comunión bajando por la calle. La comitiva la encabezaban dos niñas de 10 años vestidas de 
ángeles ${ }^{17}$. Antes de entrar en la iglesia, todas las madres se afanaban en arreglar la apariencia de sus hijos e hijas. Era entonces -leemos- «cuando Tulita tuvo terribles escrúpulos» (Picazo et al., 2005: 144) porque la noche anterior se le había quedado un trocito de carne entre los dientes y se lo había tragado por la mañana. Después de que Tula le asegurara que el hecho carecía de importancia, la comitiva entraba en la iglesia recibida por el cántico de la Carmelitas en la clausura. El guion sugería una toma del retablo con una ampulosidad algo guasona: «El dorado retablo, iluminado con dispendio, es un anticipo material del esplendor de la Gloria» (Picazo et al., 2005: 145). A continuación, los niños se colocaban en los bancos y se iniciaba el recital de poemas a la Virgen que recoge la película. Es un acierto, a nuestro parecer, que Tula no se ponga «a llorar como una tonta» como sugiere el guion, sino que solo esboce con los ojos humedecidos y el temblor de sus labios la emoción del momento. Otro acierto de la película es haber incluido la escena de ir a comulgar, no referida en el guion, donde además de las niñas vestidas de blanco y algunos familiares, vemos desfilar a Amalita, Ramirín, Tula y Ramiro. Nos embarga una sensación como de "vuelta al redil", auspiciada por la mirada adusta de Tula, «poniendo medida a muchas cosas», tal y como había adelantado a Tulita en la secuencia anterior, tras la propuesta de matrimonio de Ramiro. Debemos señalar que después de dicha propuesta de matrimonio, el guion colocaba otra escena finalmente no incluida en la película, en la que Tula decidía quemar en la cocina los recortes eróticos de Ramirín y las cartas de amor de su padre. Antes de lanzarlas todas al fuego de la cocina, sin embargo, se detenía a leer otro fragmento de la carta que horas antes le había impresionado tanto. Acto seguido, como era previsible, quedaba absorta en la imagen de la llama prendiendo en el papel. El mensaje, una vez más, resultaba meridianamente gráfico, pues era casi como lanzar el deseo erótico para que ardiera en el «fuego del infierno».

Como vamos viendo, el proyecto original cargaba mucho más las tintas en el tema de la represión del deseo y la curiosidad culpable de Tula (al leer dos veces la carta), así como en el adoctrinamiento mojigato de la niña, que ni siquiera sabe jugar sin recurrir a ritos y oraciones católicas. Comentaba Picazo que le daba la impresión que los censores «siempre pensaron que se trataba de cosas [las escenas cortadas] que él había incorporado malintencionadamente» (Iznaola, 2004: 35). No podemos evitar pensar que la escena censurada del tocador, en la que debíamos ver a Tula en combinación aplicándose desodorante y ajustándose la falda sobre las caderas, además de tener cierto cariz voyeurista, sí respondía a una clara intención, sobre todo teniendo en cuenta que la escena seguía a la de la comunión. Sin ánimo de herir sensibilidades, habría sido casi como

\footnotetext{
${ }^{17}$ La película conservará una toma parecida que sirve de fondo al movimiento de Tula yendo al encuentro de su cuñado, una vez finalizada la ceremonia, mientras los niños y niñas abandonan la iglesia.
} 


\section{Gemma Suñé Minguella}

superponer al «cuerpo de Cristo» recién recibido, el cuerpo de Tula en su abrumadora sensualidad. La provocadora tensión entre lo sagrado y lo profano, «malintencionada» o no, habría resultado de lo más elocuente. No obstante, buena parte de las escenas que más molestaron a los censores, según Picazo, se nutrían del trabajo de documentación del director, tanto de vivencias reales como de libros de meditación de la época. Nos referimos a las escenas del Círculo de Acción Católica que se desarrollan después de la primera comunión de Tulita.

Recurriendo a una técnica de cierta raigambre flaubertiana ${ }^{18}$, el guion y la película original intercalaban un total de cuatro escenas simultáneas pero que acontecían en lugares diferentes y a personajes distintos: Ramiro en el Merendero y en el olivar con las prostitutas, y Tula en el Centro con el grupo de mujeres de «Acción Católica».

Después de que Tula empujara cariñosamente a Ramiro para que saliera de casa, y este se dirigiera - según el guion- a la casa que había compartido con Rosa, veíamos a Tula subir con prisas las escaleras del Centro donde, tras cruzarse con dos muchachas ensayando un baile, se unía a Herminia que estaba en el Salón de Juntas con «las novias». «Las novias», aclara el guion, «son quince mujeres de los barrios obreros de la ciudad. Algunas han traído a sus hijos. Dos están embarazadas» (Picazo et al., 2005: 152). Lo que habríamos presenciado - de haberse incluido esta escena- no era más que una de las tantas labores de auxilio social y moral (y de catolización) encomendadas a las ramas femeninas de Acción Católica, como auspiciar matrimonios católicos a los amancebados o bautizar a sus hijos ${ }^{19}$. En este caso, se trataba de proveer alimentos a estas mujeres y sus familias a cambio de que consintieran en tomar la primera comunión, previa confesión. Según les explica Herminia, debían acudir por la mañana al Centro desde donde se las acompañaría a la iglesia para la ceremonia. Se les pide que escriban los nombres de los familiares para los que quieren recibir alimentos, pero la mayoría de ellas responde que, o bien no saben escribir, o bien no traen papel. Al final, Herminia les requiere que se pongan en fila y ella misma los irá anotando. Cuando Tula se le acerca para sugerirle «bajito» quiénes deben acompañar a «las novias» al día siguiente, Herminia contesta con cierto tono de superioridad paternalista: «Claro... Dejarlas solas, imposible. Menudo jaleo...». A renglón seguido le pide que se siente a ayudarla «porque si no, va a ser el cuento de nunca acabar» (Picazo et al., 2005: 154). Resulta bastante obvia la intención de denuncia social que tenía tal escena. El aspecto de las mujeres, su analfabetismo y su depauperada situación se transmitiría a través de las imágenes, así como la actitud de disimulado desdén de quienes ofrecían pan a cambio de doctrina. No hay duda de que el llamado

\footnotetext{
${ }^{18}$ Nos referimos al efecto «sinfónico» creado en el capítulo 8 de la segunda parte de Mme. Bovary, conocido como el «Capítulo de los comicios».

${ }^{19}$ Véase Hernández Burgos (2013).
} 
«Código de Sevilla», documento interno de la Junta de Censura de 1937, vigente hasta la adopción de las ya citadas Normas de Censura Cinematográfica de 1963, difícilmente habría pasado por alto la crudeza de la escena. En el apartado de «Temas sociales» prohibía referencias «a excesos de tristezas en las clases humildes motivados por falta de medios económicos» ${ }^{20}$. Sin embargo, las Normas aprobadas con García Escudero eran más flexibles y consideraban que no había razón para evitar o prohibir escenas que plantearan problemas auténticos ${ }^{21}$. En cualquier caso, ya fuera por exceso de celo o por motivos de economía dramática, resulta curioso que, además de eliminarse esta escena, los colchoneros de la escena antes referida aparezcan vestidos sin apenas harapos y totalmente cubiertos. Un menoscabo a la verosimilitud del retrato social, indudablemente.

Acto seguido venía la escena de Ramiro en el merendero, que sufrió algunos y muy atinados cambios respecto al guion. Un gran acierto fue cambiar la música de un ciego tocando el acordeón por un twist que suena desde los altavoces del local, y que una de las parejas baila brevemente. Otro detalle muy bien "intencionado", pues el twist se había introducido en España un par de años atrás y estaba provocando furor entre los jóvenes, de ahí que el régimen quisiera acallarlo ${ }^{22}$. Al parecer, la base americana de Torrejón de Ardoz, citada en el guion como fondo del paisaje desde el olivar (Picazo et al., 2005: 166), fue uno de los puntos por donde se introdujeron las novedades musicales procedentes del mundo anglosajón. $\mathrm{Al}$ son de esta música se desarrolla toda la escena de los motoristas y sus parejas, contemplada con gran curiosidad no solo por Ramiro, sino también por una adolescente (¡asiendo un cayado!) que, en un tercer plano, admira con envidia la vestimenta y los ademanes de las chicas modernas, hasta que su madre la arrastra fuera del encuadre recriminándola. Esta graciosa anécdota no figuraba en el guion, como tampoco el momento en que una de las chicas «cachondas», que ha

\footnotetext{
${ }^{20}$ «Queda prohibido todo lo relativo a la lucha de clases, exaltación del pueblo oprimido, ni argumentos que se refieran a vejaciones a las clases obreras o referentes a excesos de tristezas en las clases humildes motivados por falta de medios económicos, por no hallar trabajo, por exceso de familia en obreros que no pueden sostener porque el jornal no cubra sus necesidades, casos de enfermedades, etc.» (Vaquerizo García, 2014: 24).

${ }^{21}$ «No hay razón para prohibir la presentación de las lacras individuales o sociales, ni para evitar lo que produzca malestar en el espectador al mostrarle la degradación y el sufrimiento ajeno...» (norma sexta); o «No hay razón para prohibir un cine que se limite a plantear problemas auténticos...» (norma séptima) (Vaquerizo García, 2014: 26)

${ }^{22}$ Además de la persecución en los medios oficiales, la Vicesecretaría de Educación Popular envió una Nota a las emisoras de radio «sobre la procedencia de no declarar radiables los discos de música twist». Entre las más que ridículas razones se esgrimían riesgo para la salud física, para el sentido del decoro y la moralidad. Las novedades musicales, sin embargo, seguían introduciéndose en el país, a través de Barajas y -sobre todo- la base americana de Torrejón de Ardoz (Molero, 2015).
} 


\section{Gemma Suñé Minguella}

advertido la mirada libidinosa de Ramiro, murmura algo al oído de la otra y estallan a carcajadas frente a él. La dimensión patética del personaje queda tan en evidencia, que casi podemos sentir su rubor. Uno de los clientes comentará entonces al camarero que un poco más arriba, en el olivar «vienen los domingos unas cuantas de Madrid. Y se organiza cada verbena...». Ramiro lo oye y se decide a ir, pero antes de que el espectador pudiera verlo, el guion original intercalaba otra escena, la de Tula, Herminia y otras mujeres de Acción Católica en el Centro meditando sobre la virginidad (Picazo et al., 2005: 158-162). Dicha escena, censurada en su totalidad, era el necesario contrapunto a la visión del deambular de Ramiro desde la casa donde vivió con Rosa (solo en el guion), pasando por la mencionada escena del merendero hasta la escena del olivar, adonde llega cuando ya las prostitutas se alejan recriminando la actitud de algunos hombres. La escena del olivar, por cierto, se inspira en una vivencia de juventud del propio director en Peal de Becerro (Jaén) (Iznaola, 2004: 36).

En la citada entrevista para el programa Versión Española de RTVE (25/04/2003), Picazo recuerda así la escena de la meditación de las mujeres: «El texto yo lo cogí de un libro de meditaciones, no lo inventé. Y sin embargo a la censura le crispó hasta el paroxismo. En esa meditación que leía Irene Gutiérrez Caba, y que las demás asumían y vivían, se venía a decir poco más o menos que en la última cena Jesucristo hizo partícipe de sus confidencias solo a San Juan... solo al Apóstol San Juan. Y se pregunta el autor de la meditación, por qué... Porque San Juan era el único apóstol virgen, los demás no lo eran. Entonces, eso hace que El Señor le haga partícipe de sus confidencias y le permita reclinar su cabeza en el hombro». Efectivamente, algo así sucede en la escena, pero hay algunos matices y detalles muy importantes que Picazo no menciona.

En primer lugar, Herminia empieza leyendo otro capítulo del libro de meditaciones, muy pertinente con la escena anterior en que ofrecía caridad a las mujeres pobres a cambio de que se «catolizaran». Este capítulo citaba el episodio evangélico en el que Jesús lava los pies de sus discípulos, y a renglón seguido conminaba a la mujer a darse cuenta de las obligaciones que ese episodio le imponía. «Hay una falsa humildad. Es la humildad...», leía Herminia, con dificultad, pues la habitación estaba casi a oscuras para favorecer el recogimiento. «Es la humildad de las palabras y de los gestos. Es la humildad que mendiga una alabanza y un aplauso. Analiza tu humildad, mujer. Ha sido así, hasta ahora, por mala ventura...».

A la lectura de Herminia, el guion intercalaba curiosas descripciones de los gestos y la actitud de las mujeres allí reunidas que sin duda se habrían traducido en planos de enorme expresividad. Las figuras femeninas, en actitudes recogidas, se repartían por la sala dejando entre sí hileras de sillas vacías. Una chica, menuda y con gafas, tomaba apuntes. Amalita, que en uno de los fotogramas aparece de rodillas y con los brazos en cruz, no es descrita así en el guion, sino sentada, estirando las piernas 
imperceptiblemente y luego recomponiendo su postura «sujetando la cabeza entre la rejilla de los dedos». Herminia, entretanto, insiste en que la lección del episodio evangélico es que hay que seguir el ejemplo de Cristo, y añade: «Es una lección difícil. Es verdad. Un ejemplo que resulta muy penoso de imitar. Es cierto...». Finalmente desiste, deja de leer, traga saliva y pregunta: «¿No os parece un poco árido...? Quizá el tema no sea muy propio... No sé...». Al comprobar que nadie le contesta, decide buscar otro pasaje hasta que encuentra el de San Juan citado por Picazo. Pero antes de ello, el guion se detenía en Tula, y las tomas, insistimos, habrían resultado de lo más elocuentes.

Tula estaba abstraída, según el guion, «se apretaba con dos dedos a los lados del entrecejo. Y tenía los ojos cerrados». Era obvio que pensaba en otra cosa, pues no había advertido que Herminia buscaba la aprobación de las demás. Más tarde, mientras Herminia lee cómo San Juan se acerca a Jesucristo «hasta recostarse amorosamente en su corazón» y cómo su figura en esta escena «aparece ante nuestros ojos nimbada de luz celestial», una de las muchachas sale de su recogimiento y se hinca de rodillas en un pequeño estrado. Con el sonido directo, se oiría el crujir de la madera, y las toses, y los leves movimientos de las mujeres recomponiéndose en sus sillas. Amalita, por cierto, no parece nada impresionada por el episodio de Jesús y San Juan, pues se dedica a retorcerse el hilo de un botón prácticamente desprendido, hasta arrancarlo y metérselo en el bolsillo, justamente cuando Herminia lee la parte sustancial del capítulo: «¿A quién amaba Jesús...? San Gregorio Niseno nos da la razón de esta preferencia: Le amaba Jesús - escribe- porque la especial prerrogativa de su castidad, le hacía digno de un mayor y más amplio amor. De entre todos los apóstoles, es Juan el único que permanecerá virgen hasta la muerte. ¿Sería extraño que el Señor le distinga con una especial preferencia, y con un particular amor...?». Tras estas palabras, refiere el guion, el auditorio se queda en completo silencio. El gesto de Amalita, arrancando hilo y botón, es muy similar al de Tula al principio de la película cuando decide cortarse las borlas de las zapatillas. Se diría que el guion insiste en la metáfora de cercenar objetos esféricos o circulares: ¿Emasculación? Probablemente.

Tras el momentáneo silencio, Herminia lee otro fragmento en que Jesucristo es denominado «Cordero Divino» que se apacienta entre lirios y azucenas: «Por eso, como dice San Juan en el Apocalipsis, las vírgenes seguirán al cordero por todas partes, adonde quiera que vaya». Es entonces cuando el guion se detiene de nuevo en Tula que, al igual que Amalita, no parece muy concentrada. Se agacha para acariciarse un tobillo, mientras conserva la otra mano sobre los ojos. A la voz pausada de Herminia, se superpone el sonido de la uña de Tula rascándose la media. Lo sagrado y lo profano se fundían de nuevo ante los ojos de los espectadores para que fueran ellos mismos los que infirieran el sentido. Y Herminia terminaba: «Renunciar, no tan solo a los placeres de la carne, sino a todo aquello que podría ser una sombra en la blancura de tu alma...». Es entonces cuando 


\section{Gemma Suñé Minguella}

Tula, para cerrar la escena, se sacudía unos hilillos blancos sobre el negro de la falda. Blancos como la blancura de esas almas castas. A buen entendedor, pocas imágenes - en este caso- habrían bastado...

Compartimos plenamente la frustración de Picazo ante la censura de estas dos escenas que tienen lugar en el Centro de Acción Católica. Si en la película solo contamos con la secuencia de la despedida de soltera para figurarnos la vida social de la mujer en la época, es indudable que - de no haber sido cortados- estos episodios habrían enriquecido enormemente el valor testimonial del film y la caracterización de los personajes femeninos, especialmente de Tula, pero no solo de ella. Paradójicamente, estos episodios, lejos de enfatizar el unánime encasillamiento de estas mujeres como «beatas reprimidas» también habrían servido para contextualizar sus vidas, y de paso atender sin prejuicios a la ambivalencia de esta asociación católica femenina que tuvo mayor repercusión social que la Sección Femenina de Falange. De manera muy sucinta, baste recordar que, aunque empezó siendo una herramienta de legitimación del régimen, la rama femenina de Acción Católica también ofrecía a las mujeres un espacio de socialización activo y autónomo, fuera del hogar ${ }^{23}$. La personalidad de Tula, pues, y ese «respeto de sí misma» que aduce ante el confesor para no ceder ante el acoso de su cuñado, resultaría mucho más coherente y menos, hasta cierto punto, arbitrario. También Herminia y Amalita habrían ganado en matices. Herminia habría acentuado la dicotomía en la que vivía: ferviente apostolado social hacia la galería y acuciante pavor a la soledad en su intimidad, algo que revela posteriormente en su advertencia a Tula de que no van a casarse. En cuanto a Amalita, su típico papel de "graciosa" habría quedado suavizado, pues este episodio habría constituido un contrapunto entre el infantilismo de sus primeras escenas y la rocambolesca y desenfadada actuación en la despedida de soltera.

Claro que no olvidamos el tono ligeramente guasón que el guion daba a todas estas secuencias, incluido el llamativo efecto de intercalarlas a las escenas de Ramiro buscando un desfogue a su incontenible libido. Un tono que fue interpretado por los censores como irrespetuoso y, por lo tanto, merecedor de la citada norma 14 del Código de censura. Pero la pátina algo burlona no entorpece para nada su peso realista, testimonial y hasta dramático, diríamos, al contrario. A nuestro parecer, el sutil humor con que se describen las escenas evita en el fondo que lo que allí se muestra resulte demasiado ridículo por rígido.

La última escena de esta serie era la de Ramiro en el olivar con las prostitutas de Madrid. La puesta en escena presenta pocas diferencias significativas respecto al guion. La pelea que se describe es muy similar. Hay un detalle de la conversación entre Emilio y Ramiro, no obstante, que

\footnotetext{
${ }^{23}$ Con el tiempo, y avalándose en textos del Concilio Vaticano II se pasaría incluso de una tímida demanda del derecho a la educación y al trabajo, a reivindicar la paridad de derechos y obligaciones con el hombre (Moreno Seco, 2003).
} 
creemos significativo. Se trata de una parte de la intervención del primero que queda solapada por el ruido ambiental. Cuando Emilio reconoce que ya su madre «se lo había imaginado» que Tula y él se acabarían casando, y Ramiro replica enojado que «eso es mucho suponer», Emilio contesta: «No, hombre. Ahora, así..., de repente, no. Pero al tiempo...». En la película solo se oye «con el tiempo...». Este pequeño detalle, de haberse oído, unido a otros ya mencionados, habrían podido inclinar la balanza en la percepción del espectador un poco más a favor de Tula. Las palabras: «Ahora así de repente no» confirmarían la razón del estupor de Tula cuando Ramiro le propone matrimonio, o cuando un tiempo atrás le había dicho que él podía volver a casarse, y ella le había replicado: «¿Casarte...? ¿Pero es posible que lo digas estando aún caliente el cuerpo de mi hermana?» (Picazo et al., 2005: 114).

La toma final de la escena en el olivar sufre también un ligero cambio que repercute en la identificación contextual de la historia. Según el guion, había de verse a Ramiro caminando solo por la carretera mientras se encendían a lo lejos las luces de la Base americana de Torrejón de Ardoz. Es probable que en un primer momento se hubiera querido mostrar la base como una suerte de protesta, pues se había convertido en un símbolo de la cooperación de los Estados Unidos con el régimen de Franco tras los Pactos de Madrid de 1953. Aunque, como ya hemos comentado, también era por ella por donde se introducía la música más contemporánea. En cualquier caso, la referencia se omite y, en su lugar, la película muestra cómo una de las prostitutas se introduce en un Seat 600, mientras sus compañeras se alejan en compañía del proxeneta. Ramiro, en efecto, se queda al final solo en el encuadre.

Después de la escena del olivar, el guion nos mostraba a Ramiro volviendo a casa bastante tarde e intentando no hacer ruido al entrar, pues ya todos estaban acostados. La voz de Tula desde la alcoba, sin embargo, le recordaba que le había guardado la cena (una rodaja de merluza y unas patatas fritas). Ramiro apenas comía nada y se acostaba. Viene entonces su noche en vela con pocas diferencias respecto al guion, salvo el hecho de que la cámara capta en su primera toma la fotografía de su difunta esposa, algo a lo que no se aludía. A la mañana siguiente se produce la violenta escena de la agresión. Resulta curioso cómo Picazo se refiere a esta escena. Cuando Enrique Iznaola se refiere a ella como «intento de violación» Picazo contesta: «Más que violarla lo que el hombre intenta decirle es jsincérate coño y reacciona!» (Iznaola, 2004: 35). Pero lo cierto es que no es así como se percibe la escena, en absoluto. La intensidad de su forcejeo y el aspecto y la expresión de Tula cuando al fin se refugia en el baño no parecen los de una simple llamada de atención. El guion, además, añadía que Ramiro, al golpear la puerta del baño, gritaba con frustración: «¡Beata!», algo que creemos habría repercutido negativamente en la percepción del personaje, pues a la agresión física sumaba una agresión verbal tendente a ofender a su cuñada. Hay quien pudiera verlo, sin 


\section{Gemma Suñé Minguella}

embargo, como una atribución justificada, sobre todo si se concibe como crítica a la educación católica de la época, represora del deseo sexual. Para los censores, sin embargo, no era más que una confirmación de que el director quería presentar a Tula como una mujer reprimida por beata, y no como una mujer virtuosa. El informe de los censores, además, pedía recortar esta escena, abreviarla hasta el momento en que Tula da con la espalda en el quicio de la puerta, con lo cual se habría perdido la mitad de su intensidad ${ }^{24}$. Afortunadamente, la escena nos ha llegado íntegra y con ella lo que es a un tiempo el momento más virulento y el clímax de la historia.

El siguiente capítulo de la película se sitúa en el pueblo, y aquí además de unos cortes practicados por la censura-: la alusión a los cascos de guerra, la frase alusiva a las iglesias del pueblo y el primer beso de Ramiro a Juanita en la cama, hubo también algunas modificaciones y añadidos de gran calado en la puesta en escena. Por ejemplo, al llegar el autobús al pueblo, la atención se situaría en una señora pálida y sudorosa que se habría mareado durante el trayecto. La comicidad costumbrista de la escena se habría rematado con sus palabras: «Ay, Dios santo. Creí morir. He echado hasta los quiries» (Picazo et al., 2004: 174). Ya en la casa, cuando los huéspedes se sientan en la sala, se crea una clara complicidad entre las dos féminas (Tula y la niña) y los dos varones (Ramiro y su hijo). Ramirín está situado de pie junto a su padre leyendo, probablemente El Jabato ${ }^{25}$, y en un momento dado se miran. Acto seguido, el niño, en un gesto tierno, besa la cabeza de su padre sin que este reaccione. Este detalle no figuraba en el guion. Parece obvio que se creó como contrapunto a otro momento poco posterior en que Tula mordisquea un melocotón y le da el resto a Tulita diciendo: «Para ti, mi vida...». La tensión entre lo masculino y lo femenino, que ha ido in crescendo a lo largo de otras muchas escenas, culmina aquí claramente con este alinearse de los niños, y la «electricidad» que se desprende de miradas, gestos y elocuentes silencios entre Tula y Ramiro.

La escena del jardín, filmada en la Real Fábrica de Paños de Brihuega (Guadalajara) suaviza un poco la tensión entre sexos y la transforma en una oportunidad. Nos referimos a la ya muy comentada y sugerente mirada que Tula, con una rosa en la mano, dirige a la espalda de su cuñado y de la que este no puede evitar percatarse. La escena, por cierto, viene precedida

${ }^{24}$ «Abreviar el plano del asalto del cuñado a Tula, cortando desde el momento en que esta al ser empujada da con la espalda en el quicio de la puerta». Expedientes de La tía Tula, núm. 29.867 y núm. 32.801. Secretaría de Estado para la Cultura, MEC (Vaquerizo García, 2014: 164).

25 Suponemos que era El Jabato porque en la escena bastante anterior de la proposición de matrimonio de Ramiro, este le pide a su hijo si puede ir a comprarle una cajetilla de cigarrillos, y Ramirín le ruega que le dé un poco más de dinero para E1 Jabato. El Jabato fue una famosa serie de historietas parecida al Capitán Trueno publicada por la editorial Bruguera desde 1958 hasta 1966. 
de un travelling a lo largo de las avenidas del jardín muy parecido al de la salida de la iglesia después de la comunión de Tulita. En ambas ocasiones, Ramiro y Tula, separados por los bancos en la iglesia o la vegetación en el jardín, avanzan por el corredor mirándose.

En la parte cortada en el jardín se oían las explicaciones del tío Pedro sobre cómo había quedado todo aquello tras la guerra civil. Explicaba que había plantado perejil en unos cascos italianos porque «así por lo menos servían para algo», también refería que le había costado mucho trabajo reconstruir la casa: «no había un cristal sano» y lo reñida que había sido la contienda: «...La que tuvimos aquí... Nos echaban ellos. Los echamos nosotros... Qué feria. Que nos pegamos bien...». Tula, por su parte, preguntaba: « $i$ hay bastantes iglesias para las necesidades del pueblo?... Y de sobra», replicaba el tío (Picazo et al., 2005: 182). La censura difícilmente podía dejar pasar los comentarios del tío Pedro a lo que fue una de las más importantes victorias del ejército republicano tras varios avances y retrocesos de ambos bandos: el Corpo di Truppe Volontarie y el ejército franquista por una parte, contra las Brigadas Internacionales y las tropas republicanas por otra. La llamada «Batalla de Guadalajara», cuyo foco principal estuvo en una Brihuega tomada por lo italianos, fue motivo de gran desprestigio para Mussolini y sus mandos militares. La mención a los cascos italianos convertidos en macetas para que al menos «sirvieran para algo» era una diáfana alusión a la gran cantidad de material bélico italiano destruido o abandonado en el campo de batalla, amén de las numerosas bajas.

Otro cambio significativo de la película respecto al guion fue la caracterización de Juanita, que habría afeado aun más si cabe los actos de Ramiro. Recordemos que Unamuno concibió a este personaje como una joven hospiciana «enfermiza y pálida [...] de maneras sumisas y mansas, de muy pocas palabras, triste casi siempre» (Unamuno, 2003:136). Manuela, la criada víctima de abuso sexual ${ }^{26}$, convertida en el film en la prima Juanita, se concebía en el guion como una muchacha rubia y desmedrada, a la que le colgaban los picos de la enagua debajo del vestido y tenía las piernas algo arqueadas. Además, sufría de un defecto en un ojo que intentaba disimular con un mechón de pelo y su comportamiento era de lo más irracional, detalle que sí se conserva hasta cierto punto en la película. Tanto sus actos como su aspecto implicaban cierto déficit en su desarrollo intelectual. En el guion se ponía a correr de repente y «sin venir a cuento» se asomaba junto a Ramirín para recitarle el conocido trabalenguas o canción que la censura también modificó, pues les molestaba que se aludiera a «la mujer de un canónigo» y pidió que se cambiara. La solución

\footnotetext{
${ }^{26}$ Es la propia Tula unamuniana la que pronuncia la palabra «abuso» y exige a Ramiro que pida perdón a Manuela: «[...] esa pobre hospiciana, de la que estoy segura que estás abusando» (Unamuno, 2003: 137). Y más adelante: «Aquí tienes a tu amo, a Ramiro, que te pide perdón por lo que de ti ha hecho» (Unamuno, 2003: 139).
} 


\section{Gemma Suñé Minguella}

fue cambiar la palabra «canónigo» por «mándigo», pero conservando el resto. Antes de abandonar el jardín, Juanita veía la rosa cortada por Tula abandonada sobre el muro, y la recogía y se la devolvía atropellándose con las palabras (Picazo et al., 2005: 182-183). El detalle de la rosa era una clara anticipación de la suerte de «triángulo erótico forzado» que iba a crearse en el espacio de unos días. En cualquier caso, el retrato que el guion hacía de Juanita la convertía en una víctima todavía más vulnerable, tanto física como psicológicamente, de la ominosa violación que tiene lugar al final de la secuencia.

La secuencia de la despedida de soltera de Jovita (Picazo et al., 2005: 192-201) es una de las más unánimemente alabadas por la crítica, debido a que brinda un contundente retrato social y psicológico del mundo femenino en ese tiempo y lugar. El guion, no obstante, nos ofrecía una imagen incluso más cruda de lo que allí acontecía. Al parecer fueron los propios productores los que, alegando «necesidades comerciales», realizaron ajustes a esta secuencia eliminando algunos planos (Vaquerizo García, 2014: 164). Recuerda Picazo que para el episodio se inspiró en las meriendas que su madre preparaba para sus alumnas el día de su santo, fiestas llamadas «cachupinadas» en las que se montaban numeritos como el del film (Iznaola, 2004: 35-36). Originalmente, el guion subrayaba la carga erótica de las canciones y de algunas conversaciones, así como la faceta devota de Tula y Herminia. Estas dos, además, se mostraban especialmente críticas y hasta un poco chismosas con sus amigas. En el afán por suprimir lo que pudiera subrayar «la beatería de Tula y sus compañeras de congregación» ${ }^{27}$, se suprimió la imagen de Herminia llegando a la casa con el velo en la cabeza (aunque Tula lo lleva en la mano junto al misal) y también el consejo que daba Tula a la futura novia de ir a la misa de velaciones en cuanto llegara a $\mathrm{Caracas}^{28}$.

Otra escena suprimida en la puesta en escena giraba en torno a la ropa interior de Jovita, en concreto un camisón de tela transparente de seda natural que su novio Rubén le había mandado por la TWA. Cuando la

\footnotetext{
${ }^{27}$ Marcelo Arroita-Jáuregui (crítico, actor y escritor, además de censor) resumía así los reparos que tenía la censura con el tratamiento de la figura de Tula: «La historia de La tía Tula puede ser abordada, cinematográficamente y sin apartarse ni una coma de este guion, de forma que resulte una película absolutamente prohibible. Basta para ello con exagerar un poco, en el mal sentido, las tintas de la beatería de Tula y sus compañeras de congregación, basta con dar un tratamiento buñuelesco al tema y presentar a Tula no como una mujer virtuosa sino como una mujer reprimida... Sin hacer de Tula ni una santa de alfeñique ni una obsesa de la represión del sexo» (Informe de Marcelo Arroita-Jáuregui Alonso del 22-4-1963, Archivo General de la Administración [AGA], caja 4.044).

${ }^{28}$ La misa de velaciones se celebraba después de la ceremonia nupcial y su cometido era propiciar que los hijos de la nueva pareja se educaran cristianamente, incluso que alguno fuera sacerdote. Se trata en realidad de un rito muy antiguo consistente en colocar un velo sobre los novios, rastreable desde el tiempo visigodo y la sociedad mozárabe.
} 
novia confirma a sus amigas que el escote es «estilo Madonna», añade que fue Clarita, la bordadora que le había hecho la ropa interior, quien se lo había aconsejado por ser «más sugestivo», a lo cual responden admiradas: «Ay que ver Clarita... Está muy avanzada». A continuación, Herminia y Tula pasaban a la habitación de Jovita para dejar sus velos y misales sobre la mesa. Herminia comentaba a Tula que encontraba excesivo lo del camisón y luego contemplaban el retrato del novio venezolano que la novia tenía sobre el tocador. Herminia le anunciaba entonces a Tula que una de sus conocidas «iba a casarse con un negro», a lo que Tula replicaba «iQué ganas de hombre!». Por último, cuando Herminia comentaba que Jovita tenía bonito su cuarto, Tula consideraba que sí, «pero un poco infantil». Esta vertiente de "criticonas" de Tula y Herminia culminará después de los cantos cuando Tula, con un canapé en la mano, dirá: «Has visto Amalita... Caramba con la tonta...», lo cual mostraba hasta qué punto llegaba la hipocresía de las que en cualquier otro momento se las daban de buenas amigas. El retrato del grupo de mujeres y sus relaciones resultaba pues algo menos idealizado de lo que la película finalmente nos muestra.

Otros detalles que faltan en la película son una de las canciones liderada por Amalita que se refería a la noche de bodas en Groenlandia en la que los novios dormían «muy juntitos» por el frío, así como la imagen de dos de las mujeres saliéndose del improvisado coro por sentirse avergonzadas de tanta alusión erótica. Amalita, sin embargo, parece disfrutar como nunca con la representación.

Por último, reseñar un fragmento de conversación alusiva al abuso sexual por parte del clero que sin duda no habría agradado para nada a la censura. Tenía lugar entre tres de las invitadas que en tono serio comentaban: «Te digo que ese dominico, le vas a besar la cruz del Rosario y te pone la mano debajo» (Picazo et al., 2005: 201).

La última escena de la película, localizada en la estación de tren donde Tula ha acudido a despedir a sus sobrinos y cuñado, es de una gran expresividad y fuerza emotiva. Los niños, muy pendientes de su padre, se agarran del cuello de Tula y se ponen a llorar cuando su tía debe bajar del convoy. Juanita está muy cambiada, su embarazo ya es visible bajo su amplio vestido y se ha peinado como una señora. $O$ la han peinado, pues también lleva unas gafas de sol que, según el guion, «se las habían puesto», quizá para disimular el defecto en el ojo que el guion preveía y que la película no recoge, o quizá para subrayar una vez más su leve discapacidad intelectual. Resulta algo cruel, pues, que Tula casi desdeñe besarla, aunque su reacción podría explicarse teniendo en cuenta que se siente desplazada por ella en su faceta de madre de los niños y, hasta cierto punto, en su vertiente de «esposa» de Ramiro. Después de despedirse de Ramiro y rogarle que no dejen de venir el día de los Santos para que los niños «bajen a ver a su madre», el tren arranca y la cámara sigue en 


\section{Gemma Suñé Minguella}

travelling a Tula que camina en paralelo al tren en marcha ${ }^{29}$, hasta que este sale del encuadre. El último plano nos muestra a una Tula compungida, apretando el puño como queriendo retener lo que sus manos acaban de dejar ir: los rostros de los niños pegados al cristal y las manos de su cuñado. Al final abre la mano, enfundada por cierto en un guante negro, y la agita en señal de despedida, al tiempo que pronuncia para sí el nombre de su cuñado. Es entonces cuando el espectador comprende, quizá al tiempo que el propio personaje, que ella tal vez le amaba.

Tras esta conmovedora e implacable escena, el guion preveía una escena epílogo que tenía lugar justamente un lluvioso día de Todos los Santos. En ella veíamos a Tula bajo un paraguas extendiendo pedazos de plexiglás sobre la tumba de su hermana, y a Herminia y Amalita que, brincando entre los charcos, buscaban a un padre que les rezara un responso. Cuando estas le preguntaban a Tula si había venido su familia, ella respondía que no porque el viaje era muy largo y Juanita, debido a su embarazo, tenía muchas molestias. Tras comentar la fatalidad que eso suponía, y quedar en que irían a buscarla para la Novena de Ánimas, el último plano nos hubiera mostrado a una Tula completamente sola en el cementerio y el agua de la lluvia «que le caía en canalillos por la manga del abrigo». Comentaba Picazo en la citada entrevista para Versión Española que ese final llegó a rodarse, pero que no se incluyó en el montaje final porque «aunque era una bonita rúbrica», el modo como se rodó el plano final del tren lo había dicho todo: «En cuanto desaparece el tren, esa soledad en la que queda, y el balbuceo diciendo Ramiro, creo que estaba dicho todo. Era la soledad absoluta, ya no iban a volver».

Estamos con Picazo en que el plano final de Tula en la estación es suficientemente expresivo, expresividad reforzada por el simbolismo del tren partiendo de la estación como «oportunidad/felicidad» alejándose definitivamente de su vida. Sin embargo, el valor del epílogo proyectado tampoco era nada desdeñable, sobre todo para rescatar esa imagen de Tula lamentando la pérdida de Ramiro y ubicar al personaje de nuevo en su cotidianeidad, sola, sí, pero no abandonada como en la estación, sino atareada de nuevo, honrando la memoria de su hermana e insertada en su círculo social. En cualquier caso, es cierto que ambas escenas transmiten una intensa carga de desolación, sobre todo teniendo en cuenta su ambientación: el tren en marcha y la soledad de la estación, por un lado, y la lluvia y el día de los Santos por otro. El último párrafo del guion subrayaba esa desolación: «A estas horas del mediodía, es casi la única que permanece en el cementerio» (Picazo et al., 2005: 209).

Hay que tener en cuenta además que, de haberse conservado ambas escenas, el final de la película hubiera sido muy similar al de Calle Mayor de

${ }^{29}$ El travelling nos deja ver a otras figuras despidiendo a conocidos en el tren, en concreto la figura de un párroco es especialmente reconocible. No hay duda de que Picazo quería que fuera así. 
Bardem, algo que Picazo siempre quiso evitar. Recordemos que las últimas escenas de Calle Mayor nos muestran a Isabel dejando partir el tren hacia Madrid, a pesar de las repetidas exhortaciones de Federico ( ${ }_{i}$ Tiene que vivir!»), su paseo de vuelta a casa bajo la lluvia por la calle Mayor, donde es objeto de burla una vez más, hasta terminar con un primer plano tras los cristales azotados por la lluvia. Cuando a Picazo se le hacían notar las similitudes entre ambas películas en su retrato de la vida provinciana, este replicaba que no tenían nada que ver la una con la otra, porque sus puntos de vista eran muy diferentes (Iznaola, 2004: 34). En efecto, en Calle Mayor el retrato sociológico de la provincia es mucho más consciente y deliberado, mientras que en La tía Tula es implícito y se aborda más como contexto de la trama, la cual se desarrolla sobre todo en el ámbito doméstico. Aun así, no hay duda de que la cerrazón y el aislamiento del mundo provinciano es un condicionante de gran calado en los destinos de ambas protagonistas. Pero la intención de Picazo, creemos, era más bien escorar la responsabilidad de la asfixia social de provincias hacia la iglesia, mientras que Bardem cargaba las tintas en el propio engranaje social de la pequeña ciudad y el hastío de sus habitantes.

\section{CONCLUSIONES}

El análisis comparativo que hemos llevado a cabo entre el guion y la película final de La tía Tula nos ha clarificado algunos puntos y nos ha desvelado también varias claves. Para empezar, podemos apreciar que la pugna entre la intención original de Picazo y las objeciones y cortes de los censores, se dirimió en el film suprimiendo numerosos detalles y varias escenas alusivas al influjo de la religión en todos los ámbitos de la vida. A la vista del guion original, creemos que la primera intención de Picazo era ilustrar con minuciosidad y cierto tono guasón (a veces) la sociedad provinciana en su vertiente más ligada a los rituales religiosos. Una intención nada disparatada, pues no cabe duda de que lo religioso impregnaba prácticamente todas las facetas de la vida: desde oraciones en determinados momentos del día, hasta los ritos que jalonaban la existencia humana (bautizo, comunión, confirmación, boda y funeral), pasando por las festividades, la educación o incluso asociaciones que hoy en día denominaríamos «humanitarias» y que en la época se designaban con otra palabra de connotaciones devotas: «caridad». Era simplemente el mundo en el que Picazo se había criado, era su sociedad, su tiempo y sobre todo su casa, regentada por una madre ligada al partido confesional católico Acción Popular, y separada del padre, socialista y sindicalista de la UGT. Recordemos además que Picazo no llegó a casarse nunca y que estaba especialmente apegado a su madre, incluso demasiado apegado, según testimonios de amigos personales ${ }^{30}$. Aunque solo podamos sospecharlo, es

\footnotetext{
${ }^{30}$ Según Ángel Blanco, amigo íntimo de Picazo, «de su madre mejor no hablar, mejor no hablar», y según Pedro Costa, productor que estudió en la Escuela de cine
} 


\section{Gemma Suñé Minguella}

muy posible que su Tula haya adoptado gestos y actitudes de la figura materna, como la pertenencia a un grupo de Acción Católica, o el hábito de andar silenciosamente en zapatillas por la casa, o el rascarse la media con la uña mientras medita, o incluso el hecho de regalar el Kempis a un joven recién ordenado sacerdote. Un libro que por cierto se convertiría en el libro de cabecera del propio Picazo en sus últimos años en la residencia de ancianos de Cazorla (Jaén) ${ }^{31}$.

La supresión de planos mostrando al clero en el funeral, o a los niños desfilando con las monjas el día de su primera comunión, o a Tula y sus amigas saliendo de misa de ocho no repercute en exceso en la coherencia de la trama, pero despoja a la película de parte de esas minuciosas y sutiles estampas de lo cotidiano que han encandilado a generaciones de espectadores.

La supresión de las escenas en el Centro de Acción Católica, sin embargo, tienen un alcance mayor, pues desplegaban ante nuestros ojos otros ámbitos de socialización y activismo de la mujer en la época, ligada en buena medida a la iglesia y a su campo de acción. La escena de la meditación, además, tenía una función dramática importantísima, pues atestiguaba la forma como se utilizaba la doctrina cristiana para reprimir el deseo sexual en la mujer, al tiempo que -en paralelo- asistíamos al patético deambular de Ramiro y su encuentro con Emilio en el olivar, ambos en el papel de simples «mirones» (como admite Emilio), y en consecuencia tan reprimidos como ellas. El guion apuntaba además una puesta en escena inteligente y expresiva que habría logrado transmitir la atmósfera del Centro con un realismo casi diríamos cervantino (por su sutil ironía).

La escena con las mujeres de los barrios obreros de la ciudad, así como la caracterización original de los colchoneros destacaban por su denuncia social. También en este caso es lamentable que no se incluyeran, pues habrían enriquecido y ampliado el retrato del mundo provinciano. En su lugar, solo contamos con la escena en que Tula, al cobrar las rentas, distribuye la ropa de su hermana difunta entre la gente humilde que ha venido a pagarle, y amonesta a uno de los arrendatarios por sus reiterados

y tuvo la oportunidad de conocer y convivir con Picazo, este estaba «pendiente de su madre todo el día. Tenía un rollo de estos, un Edipo que era alucinante [...] Lo recuerdo como compañero, salíamos alguna noche... Y luego estaba el tema este de Guadalajara. Todos siempre estábamos sorprendidos porque así que había media hora, se iba para Guadalajara a ver a su madre. Estaba muy, muy enmadrado”. También recuerda que Picazo «trabajaba en sindicatos; debía ser el único de la Escuela que tenía un trabajo fijo» (declaraciones extraídas del documental «Miguel Picazo, el hombre que supo amar el cine», Canal Sur, 22/11/2017).

31 «He tenido altibajos respecto a la fe y la religión, pero ahora mantengo charla diaria con Él y me llena mucho, mucho la lectura del Kempis, un libro tan básico como los Evangelios» (declaración extraída de la entrevista concedida a Javier Oliveros León, AISGE, 27/03/2015). 
retrasos. Es una escena de cierta ambigüedad, pues aunque vemos que Tula está siendo generosa y paciente, la actitud sumisa de ellos y el plano final de Tula guardando el dinero recibido en su caja nos deja con una turbia sensación.

También fue deplorable que la escena de los colchoneros se redujera a la mitad, eliminando parte de su sentido, así como el retrato de una niña totalmente imbuida de superstición y lenguaje religioso, hasta el punto que debe ser su propia tía quien, antes de su primera comunión, la persuada del carácter nimio de un poco de carne en los dientes para comulgar. No hay duda de que con Tulita Picazo cargaba especialmente las tintas.

Eliminando la alusión a los cascos de guerra y a las iglesias del pueblo, la censura nos arrebató una buena dosis de ironía y un detalle que hubiera incidido en la caracterización de Tula como una «beata», algo que también quiso evitarse al eliminar esa palabra de la boca de Ramiro tras la agresión. Ya hemos comentado que esta era la preocupación fundamental de la censura: no presentar a Tula como una fanática ridícula, algo que en realidad tampoco transmitía el guion. Cierto que había más carga religiosa y algunos detalles que contribuían al retrato intencional de Picazo de pintar una mujer «soberbia de creerse solo merecedora de culto metafísico» ${ }^{32}$, pero algunas intervenciones y actos de los personajes recordando cuán reciente era la muerte de la hermana, hacían más comprensible el rechazo de Tula a su cuñado. En cuanto a su personalidad, el guion nos hacía un retrato más complejo de Tula, menos de una pieza, pues aparte de conocerla en su faceta maternal, nos permitía verla distraída durante la meditación, chismosa en la fiesta con sus amigas, devota en varias ocasiones y hasta sensual aplicándose desodorante frente al espejo. Ramiro, que en la película se nos muestra como alguien exclusivamente centrado en la forzosa represión de su libido, adquiría un poco más de enjundia al rondar la casa donde había vivido con Rosa, pues aparte de ese momento y de una fugaz visita al cementerio, el viudo no parece excesivamente afligido por el recuerdo de su difunta esposa. Por otra parte, la caracterización de Juanita con un defecto en el ojo y algo más bobalicona que en la película intensificaban su execrable acto de violación.

En definitiva, creemos que en el guion y en las escenas cortadas subyace otra versión de La tía Tula, no simplemente un embrión de la película que llegó a ser, sino más bien la versión de lo que tuvo que haber sido. Una versión irremediablemente perdida, pero por fortuna todavía rastreable.

\section{BIBLIOGRAFÍA CITADA}

Cabañas Alamán, Fernando J. (2001), Cancionero Musical de Castilla-La Mancha, Cuenca, Universidad de Castilla-La Mancha.

\footnotetext{
32 Declaraciones extraídas de la hoja informativa del cine-club D. Bosco de Cabezo de Torres (Murcia), abril de 1969 (Rodríguez Martínez, 1992: 18).
} 


\section{Gemma Suñé Minguella}

Castro, Antonio (1974), «Declaraciones de Miguel Picazo a Antonio Castro», en El cine español en el banquillo, Valencia, Fernando Torres Editor, pág. 332.

García Escudero, José María (1978), La primera apertura. Diario de un director general, Barcelona, Planeta.

Hernán, José Miguel (2005), «Sobre la adaptación», en M. Picazo et al., La Tía Tula. Guión cinematográfico, Jaén, Diputación Provincial de Jaén, págs. 43-44.

HeRnÁndeZ Burgos, Claudio (2013), «Misioneras de la patria. Las mujeres de Acción Católica durante el primer franquismo (19361951)», en VII Encuentro Internacional de Investigadores del Franquismo, Barcelona, CEFID-UAM (CD-ROM).

HernándeZ, J. (2003), «Miguel Picazo. El reverso de la España idealizada», en C. F. Heredero y J. E. Monterde (coords.), Los «nuevos cines» en España. Ilusiones y desencantos de los años sesenta, Valencia, Ediciones de la Filmoteca, págs. 319-331.

IZNAOla, Enrique (2004), «Miguel Picazo, un cineasta jiennense», Entrevista en E. Iznaola (coord.), Miguel Picazo, un cineasta jiennense, Jaén, Diputación Provincial de Jaén, págs. 15-58.

Laurie, Edith (1965), «New changes on the Spanish Film Scene», Film Comment, 2/4, págs. 37-40.

MARTínEZ, Josefina (2006), «El cine tardofranquista, reflejo de una sociedad», en A. Mateos López y Á. Herrerín López (coords.), La España del presente: de la dictadura a la democracia, Madrid, Asociación Historiadores del Presente, págs. 333-352.

Molero, Julián (2015), Batería, guitarra y twist, Madrid, La Fonoteca.

Monleón, José (1964), «Miguel Picazo después de La tía Tula», Nuestro cine, 31, págs. 42-48.

Moreno Seco, Mónica (2003), «De la caridad al compromiso: Las mujeres de Acción Católica (1958-1968)», Historia Contemporánea, 26, págs. 239-265.

Navarrete-Galiano, Ramón (2007), «Cine y Literatura: Compromiso Social. Un ejemplo: La Tía Tula de Miguel Picazo», en F. Sierra Caballero (ed.), IX Congreso Ibercom. Iberoamérica: comunicación, cultura y desarrollo en la era digital, Sevilla, Universidad, págs. 1-20.

OCAÑA, Javier (2004), «Retrato de una dama reprimida», en E. Izanola Gómez (ed.), Miguel Picazo: un cineasta jiennense, Jaén, Diputación Provincial de Jaén, págs. 193-194.

PicAzO, Miguel et al. (2005), La Tía Tula, guión cinematográfico, Jaén, Diputación Provincial de Jaén.

RodrígueZ MARTíneZ, Joaquín (1992), Conversaciones con Aurora Bautista, Orihuela, Diputación Provincial de Alicante.

Unamuno, Miguel de (1920), Tres novelas ejemplares y un prólogo, Madrid, Espasa-Calpe. 
Unamuno, Miguel de (2003), La tía Tula, ed. de C. A. Longhurst, Madrid, Cátedra.

VAQUERIZO García, Luis (2014), La censura y el nuevo cine español: Cuadros de realidad de los años sesenta, Alicante, Universidad.

VAuCHEZ, André (1988), La sainteté en Occident aux derniers siècles du Moyen Age d'après les proces de canonisation et les documents hagiografiques, Roma, École Française de Rome [En línea: https://www.persee.fr/doc/befar_0257-4101_1988_mon_241_1. Fecha de la consulta: 10/02/2020].

Fecha de recepción: 12/05/2020.

Fecha de aceptación: 25/07/2020. 